\title{
FIRST RECORD OF Alona setigera BREHM (CLADOCERA, CHYDORIDAE) IN THE NEOTROPICAL REGION
}

\author{
SANTOS-WISNIEWSKI, M. J., ${ }^{1}$ ROCHA, O. ${ }^{2}$ and MATSUMURA-TUNDISI, T. ${ }^{1}$ \\ ${ }^{1}$ Instituto Internacional de Ecologia, Rua Bento Carlos, 750, Centro, CEP 13560-660, São Carlos, SP, Brazil \\ ${ }^{2}$ Departamento de Ecologia e Biologia Evolutiva, Universidade Federal de São Carlos, C.P. 676, CEP 13565-905, \\ São Carlos, SP, Brazil
}

(With 1 figure)

The species Alona setigera Brehm, 1931, (Cladocera Chydoridae) was initially described by Brehm (1931) as a subspecies of Alona guttata occurring in New Zealand. Smirnov \& Timms (1983), in an inventory of the Cladocera from Australia, considered it a distinct species, belonging to the genus Biapertura, based on the presence of two major head pores.

Up to the present this species has been found only in Australia, Tasmania, New Zealand and Indonesia. During a detailed study of Cladocera Chydoridae in São Paulo State (Biota Project, Fapesp) the species was found in six bodies of water in Serra da Mantiqueira, at altitudes varying from 1,800 to $1,920 \mathrm{~m}$, in the Campos do Jordão region: Santa Isabel Reservoir $\left(22^{\circ} 43.585^{\prime} \mathrm{S}\right.$; 45 $\left.25.995^{\prime} \mathrm{W}\right)$, Lake Lavrinhas I (2242.142'S; 4525.190'W), Lake Lavrinhas II (22 $41.848^{\prime} \mathrm{S}$; $\left.45^{\circ} 25.156^{\prime} \mathrm{W}\right)$, Trutas Stream (22 $43.304^{\prime}$ 'S; $\left.45^{\circ} 27.128^{\prime} \mathrm{W}\right)$, Lake Lambaris (22 $\left.{ }^{\circ} 41.405^{\prime} \mathrm{S} ; 4^{\circ} 28.985^{\prime} \mathrm{W}\right)$ and Lake Tundra (22 ${ }^{\circ} 43.304$ 'S; 45 $\left.27.132^{\prime} \mathrm{W}\right)$. Sampling was carried out in the period 9-11 November 1999. Fig. 1 shows the characteristics used for species identification.

This is, therefore, the first record of the species for the Neotropical region.

According to Sinev (1999) there are eight species belonging to the Alona costata complex: Alona costata in Europe; Alona setigera in Australia, Tasmania and Indonesia; Alona cheni in India; Alona rustica in Europe and East Siberia (although the latter species has also been recorded in Brazil); Alona hudeci in Venezuela; Alona bicolor in North America and two species Alona fabricii and Alona muelleri in Greenland. Although the species are all very similar, Alona setigera is more closely related to Alona costata. However they can be distinguished by the number of head pores, three in A. costata and two in A. setigera. The description of similar types as different species among this group has led to gradually discarding the idea of cosmopolitism.

Nevertheless, based on the morphology of the specimens found in Serra da Mantiqueira water bodies, it corresponds in detail to the diagnosis proposed for Alona setigera, as follows: body, oval; length, 1.7-1.9 time the maximum height; absence of denticles in the posteroventral corner; rostrum short and rounded; head shield with two interconnected head pores; anterior and posterior margin of head shield rounded; postabdomen narrowing distally, with dorsal edge weakly concave and distal margin truncated; preanal margin short; large anal denticles; adult female size between 0.30 and $0.49 \mathrm{~mm}$.

It is possible that some previous records of Alona guttata in Brazil actually correspond to $A$. setigera, considering that the observation of head pores, required to distinguish the species, is not always performed because it involves special preparations of the head shields. In the future, a wider geographic coverage in the sampling and appropriate identification may reveal the occurrence of this species in other Brazilian localities.

\section{REFERENCES}

BREHM, V., 1931, Cladoceran aus Neuseeland. Arch. Hydrobiol., 23: 491-501.

SINEV, A. Y., 1999, Alona costata Sars, 1862 versus related palaeotropical species: the first example of close relations between species with a different number of main head pores among Chydoridae (Crustacea: Anomopoda). Arthropoda selecta, 8(3): 131-148.

SMIRNOV, N. N. \& TIMMS, B. V., 1983, A revision of the Australian Cladocera (Crustacea). Rec. Austral. Mus., suppl. 1, 132p. 

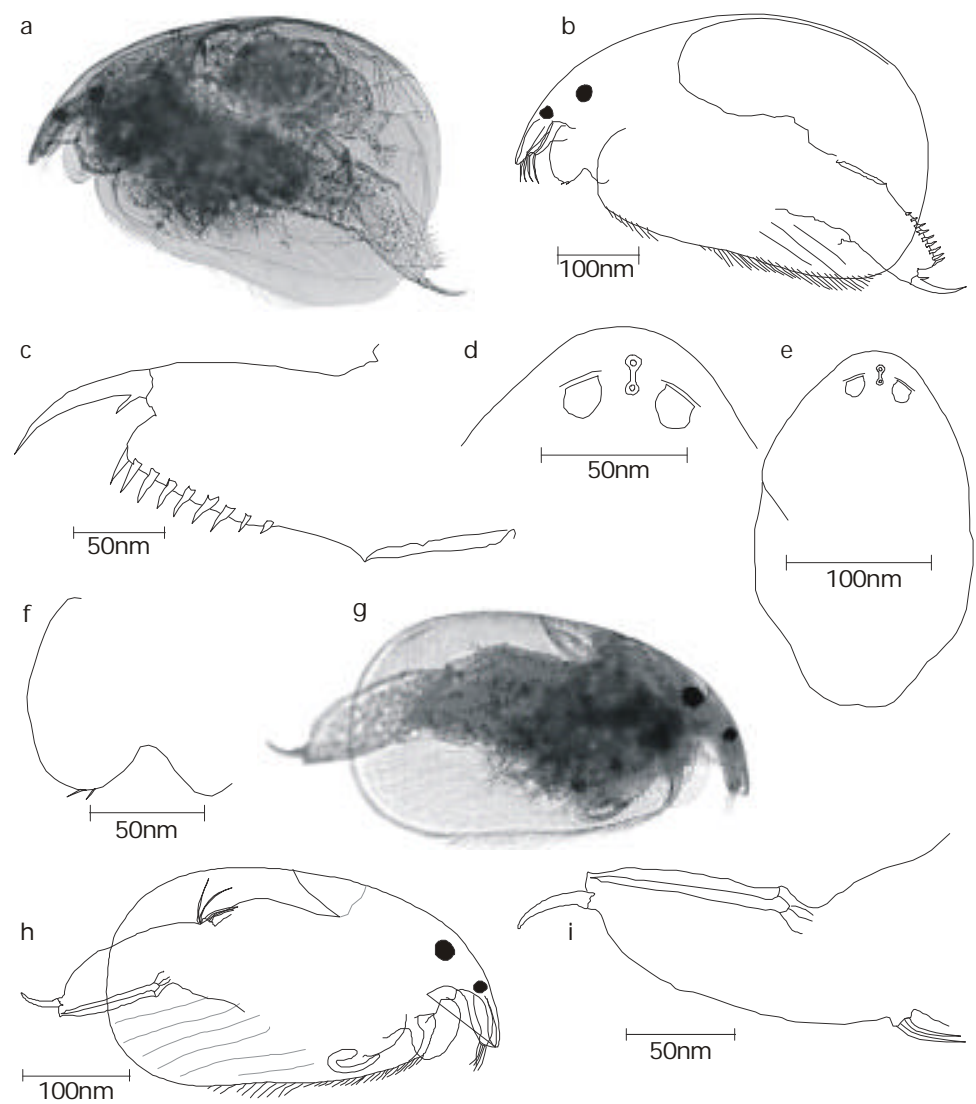

Fig. 1 - a to $\mathbf{f}$ - Alona setigera (female). $\mathbf{a}$ and $\mathbf{b}$ - general view; $\mathbf{c}$ - postabdomen; $\mathbf{d}$ - head pores in detail; $\mathbf{e}$ - head shield; $\mathbf{f}$ - labrum. $\mathbf{g}$ to $\mathbf{i}$ - Alona setigera (male). $\mathbf{g}$ and $\mathbf{h}$ - general view; $\mathbf{i}$ - postabdomen. 